\author{
Mariusz LAMPRECHT
}

\title{
HIDDEN PROPERTIES OF CITY PLANS: A CASE STUDY OF LÓDŹ
}

\begin{abstract}
The article analyses the transformations and the internal diversity of the oldest urban structures of central Łódź, one of the biggest Polish cities. 19th-century Łódź was one of the greatest centres of the textile industry in Europe. Currently, the city faces major challenges, including a dramatic population decrease, population ageing as well as a vast revitalisation of urban structures aimed at reinforcing the new idea of the city's inward development. The research on the layout of Łódź is based on the modern image of the city as well as four images preserved in historical plans. The subsequent, chronological models are analysed in terms of topological features with the use of space syntax methods. The conducted research made it possible to identify the internal, configurational diversity of the historic urban core of Łódź. A seemingly monotonous, orthogonal urban layout is, from a topological perspective, highly diversified. Due to the actions undertaken in Łódź and aimed at restoring urban structures in the broad sense, the study not only has a cognitive goal, but it also carries a practical context.
\end{abstract}

Key words: historic urban core, urban morphology, space syntax, city centre, centrality measures Łódź.

\section{INTRODUCTION}

A spatial layout is one of the most permanent and stable attributes of a city. A plan, filled with physical substance and activities of city inhabitants, is a fixed, hard-tochange framework for the social and economic processes occurring within. As a result, the urban layout may have a major influence on the society that functions in this framework. The internal diversity of a plan (the urban grain) determines, for instance, the availability of spaces or the 'permeability' of urban tissue, therefore it can spatially marginalise some inhabitants or control their mobility. This, in turn, influences the recurring diversification of the city area on the economic and social levels.

\footnotetext{
* Mariusz LAMPRECHT, University of Lodz, Faculty of Geographical Sciences, Institute of the Built Environment and Spatial Policy, Kopcińskiego 31, 90-142, Łódź, Poland; e-mail: mariusz. lamprecht@geo.uni.lodz.pl, ORCID: https://orcid.org/0000-0002-0418-1115
} 
Many cities see changes to their urban layouts over long enough term. These changes are caused by the overlapping, fading and merging of planned and spontaneous actions of the societies who live there and make use of the space. For this reason, a plan is often compared to a palimpsest, where the existing grows on the foundation of the historical (Azimzadeh and Bjur, 2007).

The present research focuses on the evolution of the urban layout of central Łódź - one of the largest Polish cities. Its purpose is to identify, firstly, the selected topological features of a city plan in subsequent historical periods and, secondly, the areas crucial to the proper functioning of Łódź. The spatial range of the analysis comprises the Historic Urban Core of Łódź, i.e. an area of its historical core of approx. 1,400 ha (almost 5\% of the city surface), inhabited by approx. $20 \%$ of all city residents. It is the area with the most intense building development, high city and culture-shaping properties and functional diversity, where the urban functions, both local and metropolitan, concentrate. Currently the actions of self-governments aimed at improving both the functioning of the city and the quality of life of its inhabitants also focus on this area.

The study's analyses were based on the theory and methods of space syntax. They enabled me to analyse urban structures, both current and reconstructed or preserved on historical plans. Space syntax theory is built on the observed correlations between space and the society that uses it. The ability to change one's own position in space, spatial thinking, understanding or remembering spatial relations, assessing the relations between objects and places in space shape human sensitivity to spatial features. That is how the configuration of space - mostly its topological aspects (e.g. the curvature of the road) and psychological ones (e.g. the good continuity principle), but also the geometrical ones (distance, angular distance, etc.) - influences the functioning of a society.

The notion of space syntax was conceived and developed by Bill Hillier and his colleagues at The Bartlett School of Architecture, University College London. The most important publications in this field include The social logic of space (Hillier and Hanson, 1984) and Space is the machine: a configurational theory of architecture (Hillier, 2007) although works that raise the issue of morphic language, such as Space syntax (Hillier et al., 1976), appeared much earlier.

The creators of the concept of space syntax defined it as a theory of space and a set of analytical, quantitative and descriptive methods used to analyse the spatial layout of buildings and cities (UCL Space syntax, n.d.). It is also described as a research program whose purpose is to search for the relationships between a society and the inhabited space shaped by material structures of buildings, housing estates, cities, etc. (Bafna, 2003)1.

\footnotetext{
1 'Space syntax is best described as a research program that investigates the relationship between human societies and space from the perspective of a general theory of the structure of inhabited space in all its diverse forms: buildings, settlements, cities, or even landscapes'.
} 
Space in space syntax is understood as relatedness. A stretch of spaces such as streets or squares that comprises material objects produces a system of connections in which a given society functions. They work as a system, whose fundamental function is to enable mobility to fulfil needs. Each element has its specific role. Local changes, such as the closing of a street or the emergence of a new one on the city outskirts, have consequences on a global scale. These changes involve not only the direction and intensity of the flows, but also constitute deep and longterm consequences on other levels, e.g. in social or economic activities or the spatial segregation of inhabitants. In space syntax, the collection of spatial relations between parts of the system (e.g. city streets), dependant on the whole system, is known as the configuration (UCL Space syntax, n.d.).

The weaknesses of space syntax include purely technical matters, such as the way of building a city model allowing researchers little room for interpretation (Kostakos, 2010; Ratti, 2004), as well as those concerning methodological and theoretical assumptions. The latter are based on accusations regarding: omitting such features of city space as its metric properties (e.g. length of streets, surface area), conducting analyses on the basis of merely two dimensions (a two-dimensional city plan), and overestimating the role of spatial configuration in the functioning of societies. Issues that appear in numerous studies, such as the edge effect, the changeability of results depending on the spatial scale of the research and difficulties in identifying and capturing the space-and-time variability, also remain unsolved (Montello, 2007; Ratti 2004; Pafka et al., 2018). The theoretical part is said to strip space of its semantic meanings and reduce social actors to unified machines trapped between material obstacles (Netto, 2016). Yet it should be emphasised that space syntax considers the vital notion of the agency of space. This agency is hard to overrate considering human adaptation to movement (spatial abilities, motor skills, etc.) shaped throughout the millions of years of evolution. Space syntax attempts to assess this agency by analysing the configuration of space and the actions of social units and groups occurring within. Space syntax seeks the social logic of space by focusing on mass observations and statistical generalisations. The identification of specific spatial models does not mean the removal of individuals' rights to their unique, unpredictable decisions. These individuals creatively configure and transform space, forming, by themselves, the urban environment.

\section{THE RESEARCH CONTEXT IN LIGHT OF SUBJECT LITERATURE}

From the perspective of space syntax, the configuration of space is perceived, analysed and assessed as a framework influencing the functioning of the societies that use it. This approach became the foundation of numerous inspiring analyses 
developed in the past decades. Those have indicated a relationship between various aspects of socio-economic life and the configuration of urban space. There are relationships with pedestrian movement (e.g. Hillier et al., 1993; Baran et al., 2008; Jiang, 2009; Sharmin and Kamruzzaman, 2018), bicycle and motor traffic (Jiang and Liu, 2009; Raford et al., 2007), spatial segregation of the inhabitants (Vaughan and Penn, 2006), land use and location of businesses (Kim and Sohn, 2002; Porta et al., 2012), rent rates and fixed property value (Enström and Netzell, 2008; Chiaradia et al., 2009) as well as the level of crime (Van Nes and López, 2010; Nubani and Wineman, 2005). In the field of space syntax, the increasing knowledge on the social and economic consequences of the spatial configuration of the urban environment has enabled the development of studies that are historical in nature (Griffiths, 2012).

City centres are one of the main subjects of historical studies on space syntax. They usually consist of valuable, old, urban structures significantly influencing the functioning of whole urban organisms ${ }^{2}$. The analyses dedicated to them usually deal with issues of various social phenomena rooted within and consider their centrality (understood differently by various entities) often in the context of the planned or conducted transformations of urban tissue ${ }^{3}$. Such research includes, for instance, the analysis of the changes in the configuration of space of Gothenburg in various timeframes. It identified the shift (dispersion) of the urban integration core, simultaneously revealing the hierarchical properties of the city's spatial structure (Azimzadeh and Bjur, 2007). Another example has involved the studies of archival maps and satellite images of Dhaka. They showed that the organic development of urbanised structures generates a plan with a higher level of integration (which reflects how close origin space is to all other spaces) and connectivity (the number of spaces immediately connected to a space of origin) of the street network (Ahmed et al., 2014). A process involving a shift of the integration core (pattern made of the most integrated spaces) within the urban space in time was also observed (Nilufar, 2010). An analysis of the transformations of Beijing old town's street network occurring throughout 100 years made it possible to discover its internal diversity in terms of structure stability, for instance its street network and active centres (Wang et al., 2018). The analysis of the changeability of the spatial structure of Wrocław has provided evidence of the integration core shifting from the historical centre to the younger part of the city, while the attributes of centrality were being preserved in the historical core (Saeid and Masztalski, 2009).

Some studies on the evolution of city plans have focussed on a given city's contemporary image and the ongoing or planned actions aimed at converting ur-

\footnotetext{
${ }^{2}$ That is all sub-components of the city, understood as an organic, complementary and cooperative whole (Marshall, 2009).

${ }^{3}$ Which can be understood, in the most general sense, as the arrangement of streets and block (Kropf, 1996).
} 
ban structures (e.g. as part of revitalisation projects). Among them there is an article on the harbour area of Rio de Janeiro (Dias and de Arruda Campos, 2015). The collapse of the harbour and the economic collapse of its district resulted in the emergence of numerous negative phenomena such as the deterioration of development, a decrease in the number of pedestrians on the streets, and higher crime rates. The city authorities responded by introducing 'Porto Maravilha', an Olympic Games-inspired revitalisation project. Its analysis showed that despite the architectural projects which improved the accessibility of individual parts of the harbour (decrease of topological distances), the urban intervention conducted had a limited influence on the general accessibility of the area. Another example offered a study of the development of the neighbourhood of the historic core of Jeddah, Saudi Arabia, conducted without a plan. In this case, the analyses focused on the search for precise, therefore also spatially restricted, effective intervention in the spatial structure of the city (Karimi et al., 2007). One of the purposes for the analysis of the configuration of a fragment of Istanbul's urban space was to suggest new communication solutions in order to decrease the level of isolation in some city areas (Önder and Gigi, 2010). Finally, Trigueiro and Medeiros (2007) have discussed the strategy of reclassifying the old centre of Natal in Brazil and the consequences of interventions planned in this part of the city.

To date, there has been no analysis of urban layout changes from a topological perspective regarding Łódź, although in the 19th century it was one of the fastest developing European cities - the fact proven by the spatial layout of its historical centre, which helps one identify several crucial stages of the city's territorial development (Fig. 1).

Although Łódź was granted a city charter in the 15th century, it was the 19th-century industrialisation that shattered the city's agricultural image. Hundreds of thousands of new residents flooded Łódź in reaction to the intense development of the textile industry. In the first half of the 19th century, the authorities controlled the city's dynamic development, maintaining its spatial constrictions imposed by a thought-out, orthogonal city plan. In the subsequent decades, the settlement upheaval was out of control. Residential developments spread along illicitly extended or chaotically marked out roads. The industry, freed from the driving force of rivers thanks to the invention of the steam engine, started settling available plots among the residential urban structures. Thus the urban structures that constitute the current Historic Urban Core of Łódź were filled in and densified.

After the end of the Second World War, the leading role of industry in the economy of Łódź was maintained in accordance with the idea of socialist economy. The construction of vast, multi-family housing estates began in areas incorporated into the city. The period was characterised by the city's major territorial development and continuing increase in the number of inhabitants with relatively small changes to the plan of its central part. 


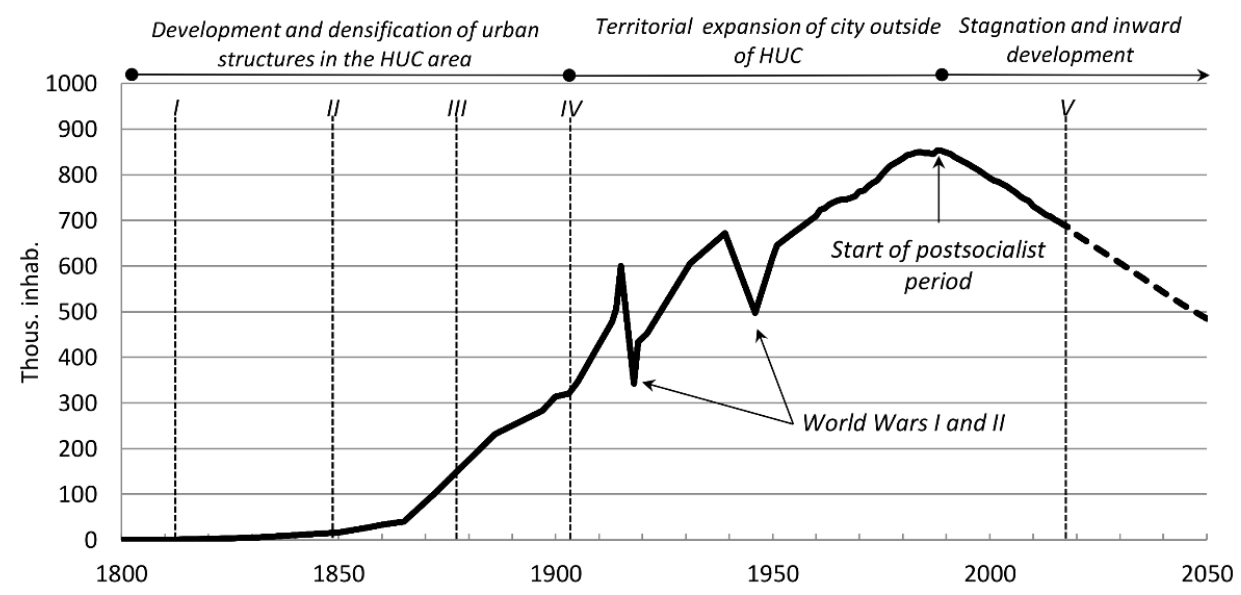

Fig. 1. Population and features of spatial development of Łódź between 1800 and 2050 The dashed line marks a forecasted number of inhabitants, according to the Łódź Population Projection 2015-2050 (Statistical Office in Łódź, 2014).

Vertical lines mark the analysed moments in the development of Łódź plans.

Source: own work.

The early 1990s and Poland's return to the path of market economy have revealed the weakness of the city's economic foundations, leading to serious social problems (a collapse of the industry, unemployment, poverty, and decreased attractiveness of the city to immigrants). As a result, contemporary Łódź features a continuous decrease in the number of inhabitants - the highest decline of the kind in the country and one of the highest in Europe. Between 1988 and 2019 , the city lost nearly 170,000 people ( $18.7 \%$ of its population). ${ }^{4}$ The loss of residents is especially strong in the city centre, where the major deterioration of the urban tissue, containing also numerous post-industrial areas, is clearly visible. It is estimated that the building development of the Historic Urban Core suffers from major decapitalisation, spreading across the area of several hundred hectares.

In the face of changes threatening the functioning of Łódź, the current strategy of spatial development intends to replace territorial expansion with inward development by, for instance, limiting urban sprawl and facilitating the thriving of the city centre. The Historic Urban Core was considered an area crucial to the city's development (Fig. 2). This, in turn, resulted in implementing a revitalisation program encompassing the central part of the city of approx. 1,783 ha (Łódź City Hall, 2020).

\footnotetext{
${ }^{4}$ The urban depopulation of Łódź is largely caused by the negative rate of natural increase. In general, it is a result of the low inflow of immigrants and the ageing of the city's population.
} 


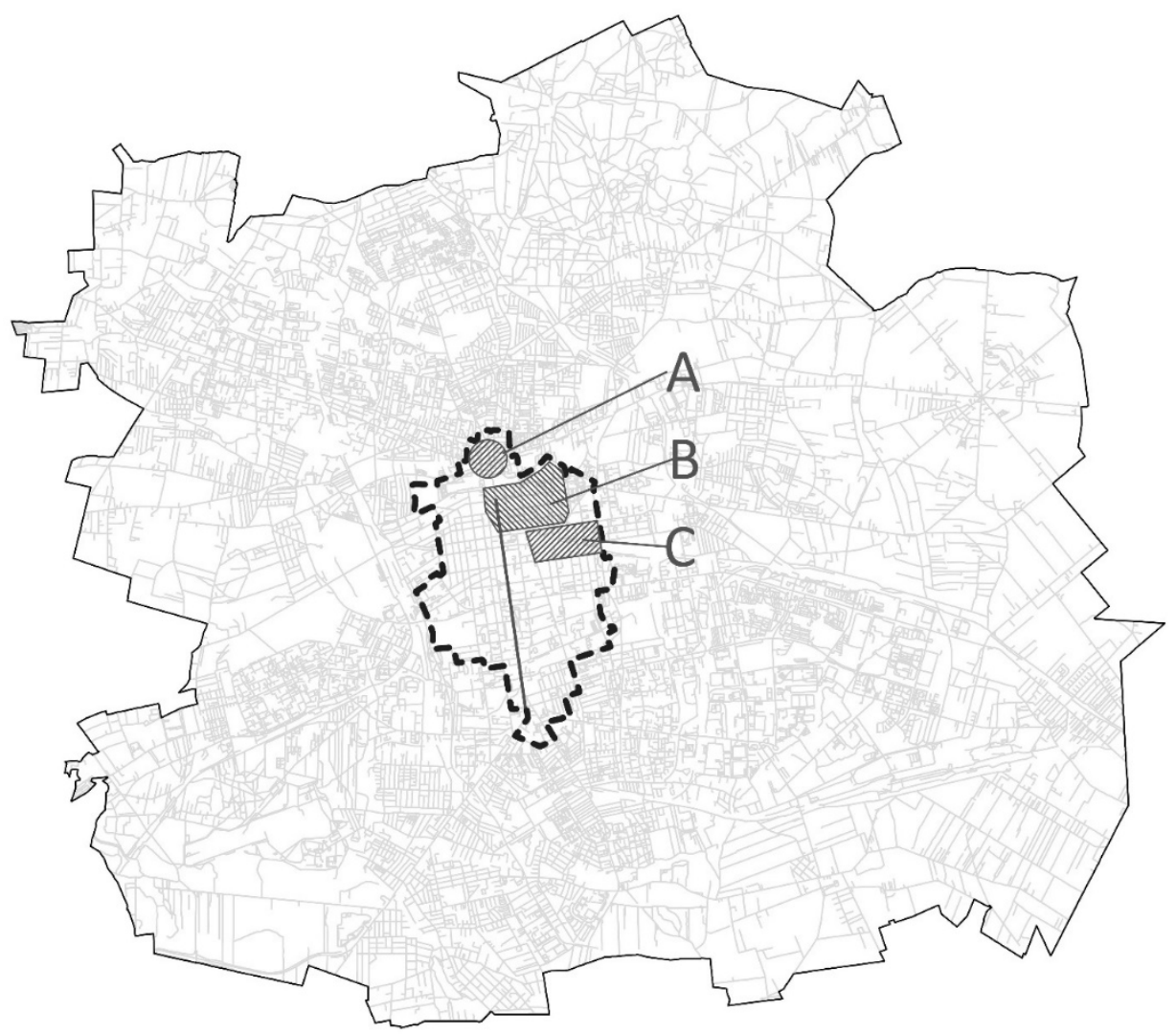

Fig. 2. Territory of Łódź and the area of the Historic Urban Core of Łódź

Dashed black lines mark the borders of the HUC. Thick black line represents the Piotrkowska street, the main street of Łódź. Hatching marks the approximate area of: A - Old Town, B - New Town, C - New Centre of Łódź

Source: own work.

Currently, the Historic Urban Core of Łódź faces major challenges. They include the restoration of the urban tissue, street upgrades, the establishment of woonerfs, as well as changes to the configuration of the street network (caused by, for instance, the construction of the New Centre of Łódź). The fact that the International Association of Horticultural Producers has granted Łódź the right to organize EXPO Horticultural in 2024 may have also provided a strong stimulus for making changes to the urban space. These transformations became an inspiration for the research on the evolution of the urban layout of the central part of Łódź presented below. 


\section{DATA SOURCES AND RESEARCH METHODS}

The presented study was based on five images of Łódź, each from a different point of its development. It comprised the modern street layout and the city's historical plans ${ }^{5}$. The adopted spatial range made it possible to analyse the changes to the spatial layout of the central part of the city from the beginning of its urbanisation to the present day ${ }^{6}$. In the case of archival plans of the city, the analysis encompassed the visible outline of streets, including those without building developments ${ }^{7}$. In the case of the contemporary image of the city, the analysis omitted transport routes intended for only vehicles or only pedestrians (such as underpasses or paths and alleys in parks), as well as spaces that did not constitute streets, e.g. car parks or the outskirts of shopping centres.

The selected plans served as the foundation for constructing the models of urban space. This process involved the transformation of subsequent two-dimensional plans of Łódź into sets of lines representing spaces (streets) of the analysed structures. There are several methods of creating a graphic representation of a city plan. The discussed study utilised a model based on natural streets (Jiang et al., 2008).

In the following stage, natural streets were transformed into dual graphs, whose vertices represented lines (i.e. streets), while edges represented line crossings (streets intersections). Further, dual graphs were analysed using selected space syntax measures (Fig. 3). Each stage of the process required the use of computer software. The vectorisation of the street network on archive maps (in the form of street axes), the corrections of topological mistakes of the current street network in the Georeference

\footnotetext{
${ }^{5}$ The modern image of the street network of Łódź was created on the basis of the Georeference Database of Topographic Objects created by the Regional Surveying and Cartographic Documentation Centre in Łódź. The historical plans and information on them were acquired from the Łódź Internet System for Area Information (Geodesy Centre in Łódź, n.d.) as well as the published collection of maps of Łódź (Janik et al., 2012). The following historical plans were analysed (identified as in Fig. 1): (I) Brulion. Plan klucza łódzkiego at 1:5,000 from 1812-1813 by Johnney, F.; (II) Rys ręczny miasta fabrycznego Łodzi at 1:10,500 from 1849 by Lenartowski, J.; (III) Plan der Grundbesitzungen samt Fabricken seiner hochwohlgeboren des Herrn Prezes Karl Scheibler mit der Umgebung der Stadt Lodz at 1:5,000 from 1877 by Miciński, R.; (IV) Ptan goroda Lodzi pietrkowskoj guberni at 1:1,680 from 1894-1896 by Starzyński, J.W. and its supplement: Płan goroda Łodzi at 1:8,400 from approx. 1903 by Chełmiński, F. and Zambrzycki, C.).

${ }^{6}$ As a result of the 20th century territorial development of Łódź, the contemporary plan differs greatly from previous ones. Currently the Historic Urban Core is merely a small part of Łódź. To preserve the spatial scale of the study and maintain internal diversity while partially reducing the edge effect, the analysed area was expanded by a street network only within $400 \mathrm{~m}$ of the Historic Urban Core. The value of $400 \mathrm{~m}$ was determined by the neighbourhood of the studied area, easy to access by pedestrians.

${ }^{7}$ It was assumed that the marked out streets presented an opportunity to move, even without a fully-developed frontage. In light of the dynamic development of Łódź in the 19th century, most of the marked out streets were quickly overgrown with urban tissue. The analysis omits communication routes in the form of twisting/sinusoidal lines that are rural in nature, visible on historical plans, since, in time, they had a tendency to disappear from city plans altogether.
} 
Database of Topographic Objects (Regional Surveying and Cartographic Documentation Centre in Łódź) as well as their export to shapefiles were carried out in AutoCAD Civil 3D (Autodesk Inc. 2020). The Axwoman 6.3 (Jiang, 2015) and Pajek32 5.08 (Batagelj and Mrvar, 2019) programs were used to generate street segments, track the transformations of street segments into natural streets, calculate syntactic measures, etc. The visualisation of the results was possible using the ArcGIS 10.4 software (Environmental Systems Research Institute, 2011).

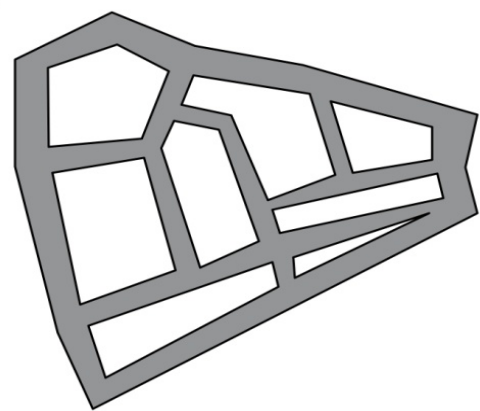

C

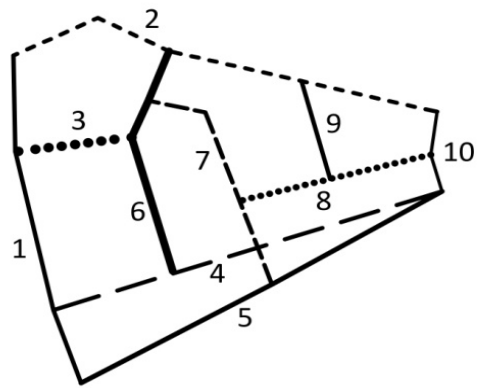

b

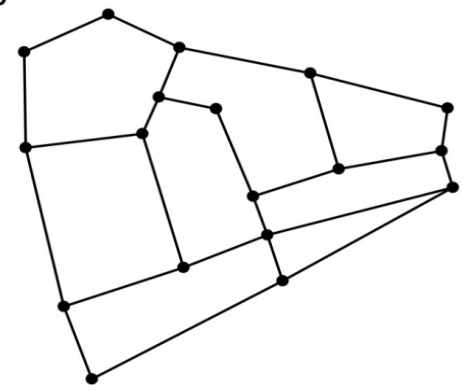

d

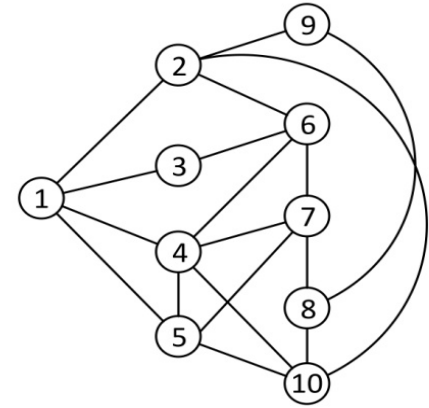

Fig. 3. Structure of a model that represents urban space

(a) a fictional city system with marked street spaces, (b) segments of street axes with marked ends, (c) natural streets, with different lines denoting separate paths of combined segments, (d) justified graph, in this case space no. 1 is a root.

Source: own work on the basis of Jiang and Claramunt (2002).

The results obtained were arranged according to the calculated values, delimiting core-ranked spaces ( $5 \%$ of natural streets with the highest values) and their supplements (another 5-10\%), secondary and tertiary routes (further 10-25\% and $25-50 \%$, respectively), as well as those of the lowest significance (the remaining 
$50 \%$ of natural streets with the lowest values) (Hillier and Hanson, 1984). In the illustration of the obtained hierarchy of the street network, thick black lines mark the highest values (well-connected or most integrated spaces) and dotted grey lines mark the lowest values (weakly-connected or most separated spaces).

Two centrality measures - choice and integration - were used to assess the urban system in Łódź in subsequent historical periods, both commonly considered crucial in the interpretation of spatial structures in cities. The goal was to identify the urban spaces that made up a city's core, or, in other words, were capable of shaping its cohesion, inhabitant-friendly conditions, safety on a local scale, clarity of the spatial layout, etc. (Scellato et al., 2006).

The choice measure suggests how often a given space may theoretically be selected by pedestrians moving through a city. High values mark spaces crucial to the flow of pedestrians, low values mark spaces of lesser or marginal significance. The choices were calculated for each apex in the graph in accordance with the formula:

$$
C h_{i}=\frac{\sigma(i)}{\sigma}
$$

where: $\sigma(i)$ was the number of shortest paths that passed through vertex i, $\sigma$ was the number of all the shortest paths.

The choice values were solely the results of the system configuration, i.e. its topological foundations. They could influence the social and economic processes within the city space. By influencing the selection of a pedestrian route, system topology can, for instance, increase the attractiveness of a location of a city areas for service entities.

Integration is a normalised measure describing the relations (topological distance) between spaces and all other spaces in a studied layout (Al-Sayed et al., 2014; Teklenburg et al., 1993). It is calculated for each apex in the graph in accordance with the formula:

$$
I N T_{i}=\frac{1}{R R A_{i}}
$$

where:

RRA $_{\mathrm{i}}($ Real Relative Asymmetry $)=\frac{R A_{i}}{D_{\text {value }}}$,

$\mathrm{RA}_{\mathrm{i}}($ Relative Asymmetry $)=\frac{2\left(M D_{i}-1\right)}{n-2}$,

$\mathrm{MD}_{\mathrm{i}}($ Mean Depth axial line $)=\frac{D_{i}}{n-1}$

$\mathrm{D}_{\mathrm{i}}($ Total Depth of axial line $)=\sum_{j=1}^{n-1} d_{i j}$

$\mathrm{D}_{\text {value }}=\frac{2\left\{n\left[\log _{2}\left(\frac{n+2}{3}\right)-1\right]+1\right\}}{(n-1)(n-2)}$

$\mathrm{n}$ - number of vertices in the system,

$\mathrm{D}_{\text {value }}$ symbolizes the Total Depth of the root in a rooted, diamond-shaped graph 
Integration values reflect the number of spaces to be crossed in order to reach all other spaces in a studied layout from a specific place. The less spaces there are to cross, the higher the integration (in the topological sense) of a place with the whole system considered. As the number of topological steps necessary to achieve all other spaces (e.g. streets in a city) increases, so does the level of separation in a place. Integration is considered a measure of the quality of city space. Places with high levels of integration can support social cohesion, make places vibrant and safe, facilitate human interaction, reduce travel times, and enhance the physical activities improving the health of citizens in urban spaces (Fathi, 2020).

\section{RESULTS}

The oldest analysed plan shows the layout of Łódź in the early 19th century. In reality, it also depicts the earlier centuries, since there was no city development at that time (the so-called period of agricultural Łódź). In light of the choice measure, the communication axis of the town at that time (current Old Town) was a longitudinal route (Fig. 4). This road was of the highest importance, also to the integration of the whole system layout (Fig. 5). The distance between the road and all other places in the analysed layout was the shortest, which contributed to its central significance. It should be emphasised that this image is reflected in the historical data, as well as the functional and spatial structures of the old town. The longitudinal axis was of major transport significance both on the regional and local scales. It led to cities of higher rank than Lódź situated further north and south. At the same time the road was the western frontage of the church and market squares, where the town life concentrated. Undoubtedly, the road was the busiest space in old Łódź, important to the functioning of the whole community.

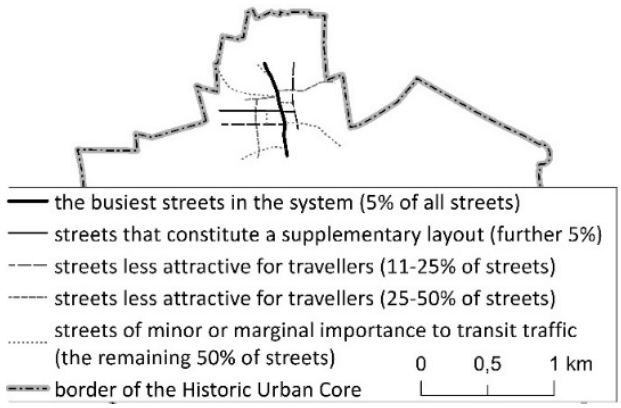

Fig. 4. Distribution of the choice value in Łódź in the early 19th century

Source: own work.

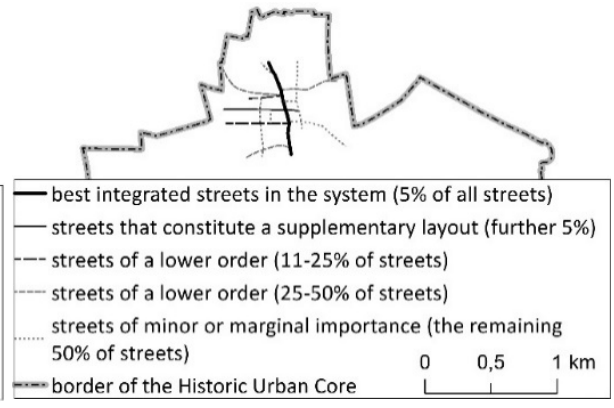

Fig. 5. Distribution of the integration value in Łódź in the early 19th century

Source: own work. 
The plan from the mid-19th century reflects the planning decisions from the 1920s, 30s and 40s, which shaped the subsequent morphological units of Łódź, quickly filled with new settlers. The Old Town axis was extended, reaching the southern edges of the modern Historic Urban Core. Its rank, in light of both centrality measures, was dominating, despite the visible city development on the right side at the time. In light of the choice value (Fig. 6), despite the geometrically-peripheral location, a stretch of roads on the western side of the layout also had a significant role. It reinforced the longitudinal axis of Łódź, creating the most topologically attractive flow spaces cutting through the area of the city at that time. The same space dominated in the integration value. The topology of the Łódź spatial layout imposed a high integration potential on this part of the city. Three latitudinal streets constituted similar integration cores at the time, although they lost their significance after further changes to the city plan were made (Fig. 7).

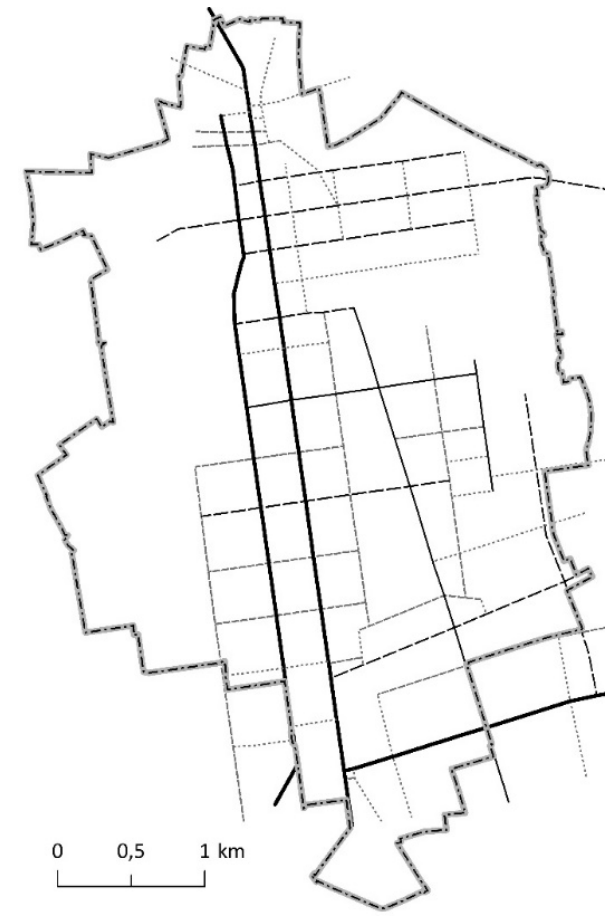

Fig. 6. Distribution of choice values in Łódź in mid-19th century (marked as in Fig. 4) Source: own work.

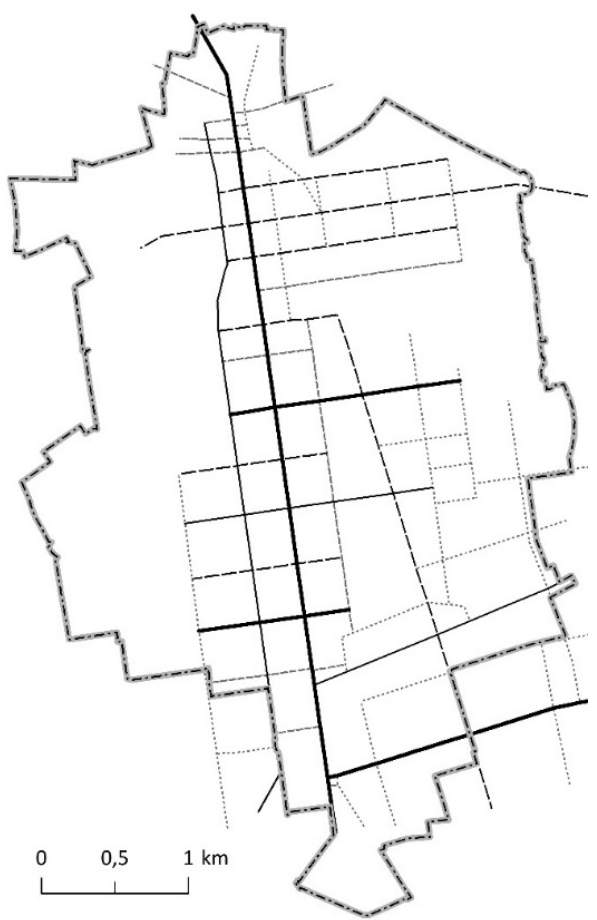

Fig. 7. Distribution of integration values in Łódź in mid-19th century (marked as in Fig. 5)

Source: own work.

As early as in the 1960s, a layout planned in such a way could not contain the subsequent waves of labourers attracted by the dynamically developing industry. In the third quarter of the 19th century, this led to a visible densification of the existing street network and, to a lesser degree, territorial expansion. It also changed, 
to some extent, the significance of streets existing prior to 1960s. In general, the spatial patterns of choice and integration measures were similar (Figures 8 and 9). They invariably constituted an axis extended from the Old Town, accompanied by another, parallel stretch of streets in the eastern part of the city. A new core with a latitudinal route appeared in the geometrical centre of this system. The three enumerated street routes would not lose their dominating position in the studied area. Yet in the eastern part of the city there is a noticeable influence of the railway, whose construction began in 1865 . It acted as a barrier preventing the merging of streets in the central part of the eastern wing of the Historic Urban Core. This image prevailed in the city plan for the next 150 years.

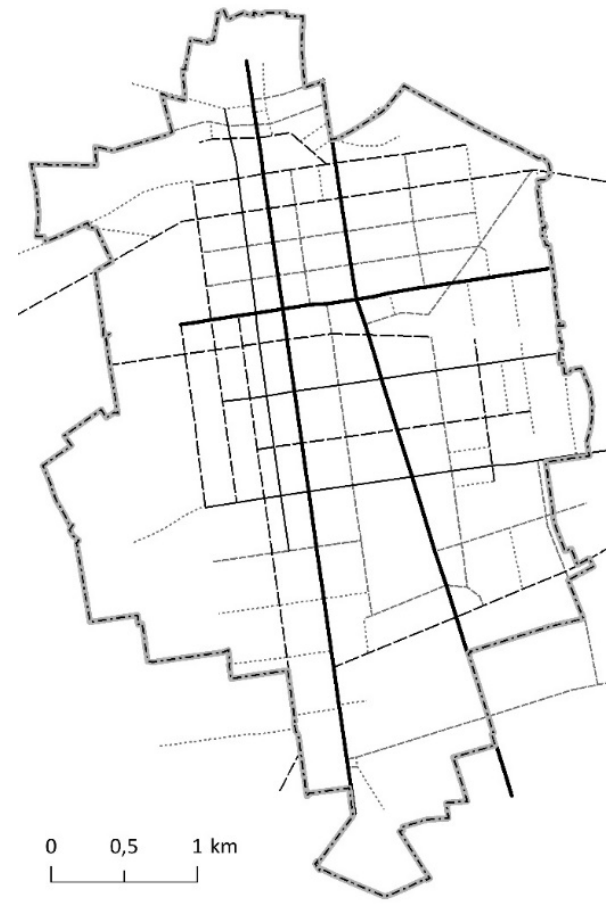

Fig. 8. Distribution of choice values in Łódź in the 1870s (marked as in Fig. 4)

Source: own work.

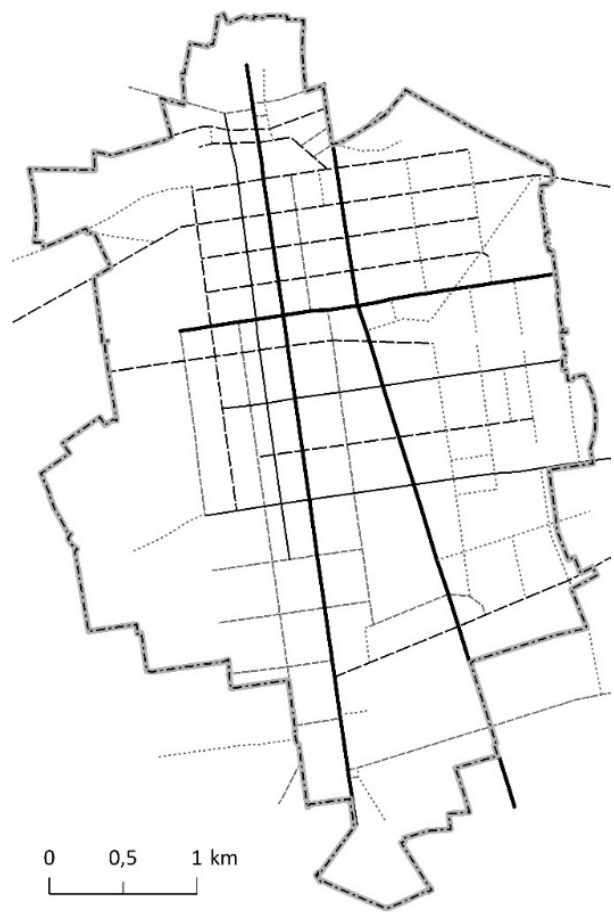

Fig. 9. Distribution of integration values in Łódź in the 1870s (marked as in Fig. 5)

Source: own work.

The end of the 19th century brought an established system of streets (Figures 10 and 11) similar to the contemporary one (Figures 12 and 13). This similarity illustrates the development of the plan of Łódź, whose 21 st-century territorial expansion was its main characteristic feature. The 19th-century urban layout filled in significant areas, which hindered changes and resulted in its freezing. As a result, the contemporary role of streets, on the level limited to the city centre, was established as early as at the turns of the 19th and 21st centuries (Table 1). 


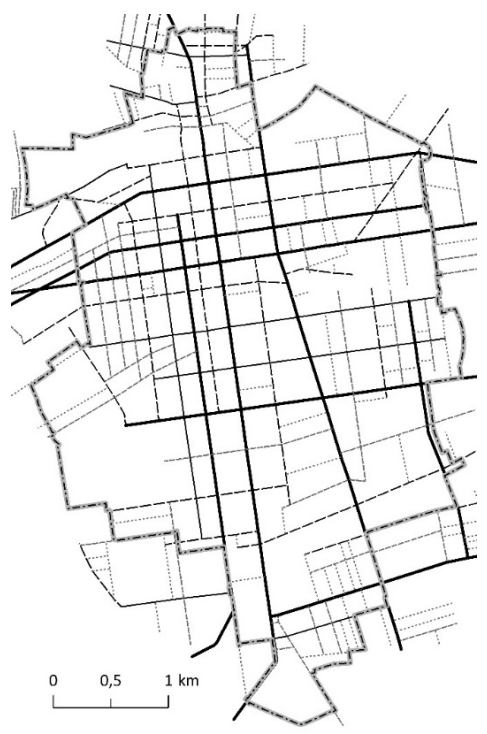

Fig. 10. Distribution of choice values in Łódź in late 19th century (marked as in Fig. 4) Source: own work.

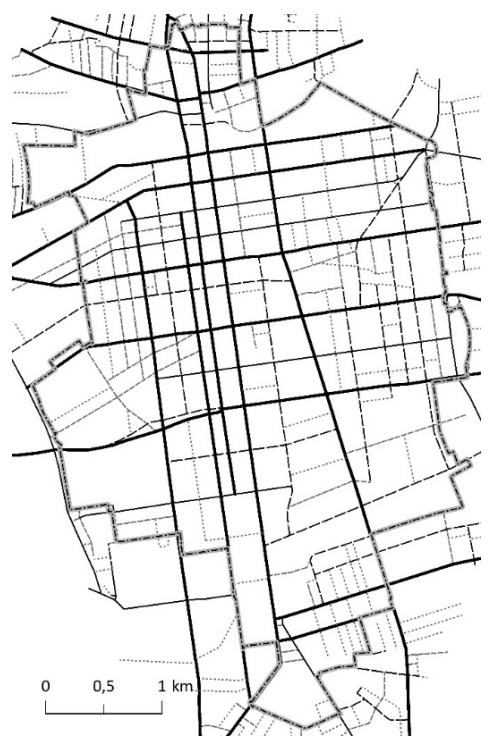

Fig. 12. Distribution of choice values in the Historic Urban Core of Łódź in the second decade of the 21th century (marked as in Fig. 4)

Source: own work.

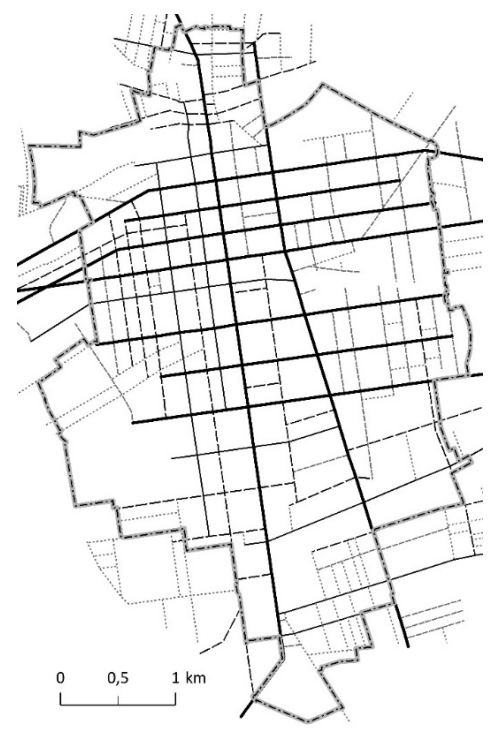

Fig. 11. Distribution of integration values in Łódź in late 19th century (marked as in Fig. 5)

Source: own work.

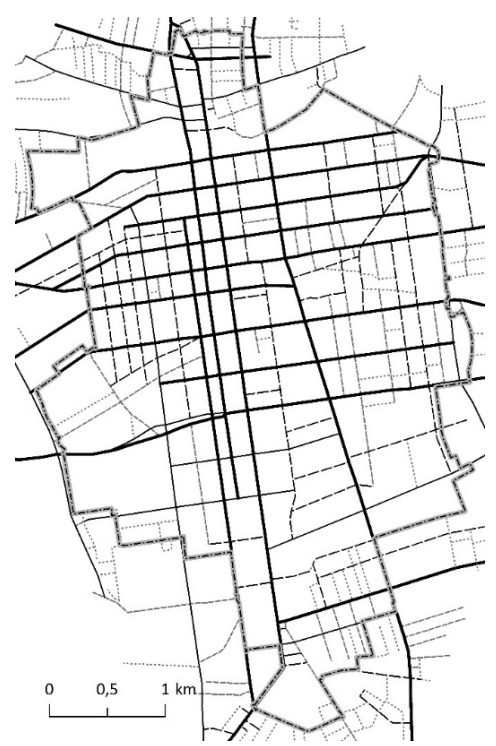

Fig. 13. Distribution of integration values in the Historic Urban Core of Łódź in the second decade of the 21th century (marked as in Fig. 5)

Source: own work. 
Table 1. Evolution of the street network within the Historic Urban Core in light of the analysed plans

\begin{tabular}{|c|c|c|c|}
\hline $\begin{array}{c}\text { Time } \\
\text { period } \\
\text { (marks as } \\
\text { in Fig. 1) }\end{array}$ & $\begin{array}{l}\text { Average } \\
\text { distance } \\
\text { between } \\
\text { intersections } \\
{[\mathrm{m}]}\end{array}$ & $\begin{array}{l}\text { Street network } \\
\text { density } \\
{[\mathrm{km} / \mathbf{1 0 0} \mathrm{ha}]}\end{array}$ & Characteristic features \\
\hline $\begin{array}{l}\text { I } \\
\text { (early 19th } \\
\text { century) }\end{array}$ & 129 & 0.37 & $\begin{array}{l}\text { Pre-industrial Łódź, plan based on medieval } \\
\text { layout. The surface area of the city was } \\
\text { a small part of the HUC. The street network } \\
\text { density was low, but the intensity of } \\
\text { connections was the highest (short access } \\
\text { routes). }\end{array}$ \\
\hline $\begin{array}{l}\text { II } \\
\text { (mid-19th } \\
\text { century) }\end{array}$ & 270 & 4.38 & $\begin{array}{l}\text { Plans of new city structures for } \\
\text { industrialisation. Street network expansion. } \\
\text { On a global scale, a major increase in } \\
\text { the density of the street network with } \\
\text { a simultaneous decrease in the density of } \\
\text { connections. }\end{array}$ \\
\hline $\begin{array}{l}\text { III } \\
\text { (the 1870s) }\end{array}$ & 251 & 5.45 & $\begin{array}{l}\text { Stage where the urban structures designed } \\
\text { earlier on were filled, inner densification of } \\
\text { the street network. }\end{array}$ \\
\hline $\begin{array}{l}\text { IV } \\
\text { (late 19th } \\
\text { century) }\end{array}$ & 172 & 7.91 & $\begin{array}{l}\text { Filling the HUC area further. A relatively } \\
\text { large increase in the length of streets and } \\
\text { the density of their connections. Beginnings } \\
\text { of the expansion of the street network } \\
\text { outside of the studied area. }\end{array}$ \\
\hline $\begin{array}{l}\text { V } \\
(21 \mathrm{st} \\
\text { century) }\end{array}$ & 162 & 8.71 & $\begin{array}{l}\text { Only slight changes despite the passage of } \\
\text { time (over } 100 \text { years), frozen street layout. } \\
\text { Expansion and development of urban } \\
\text { structures outside of the HUC. }\end{array}$ \\
\hline
\end{tabular}

Source: own work.

Both choice and integration quite explicitly set a contemporary, configurational centre, crucial to the functioning of the Historic Urban Core. It constitutes an axis that is genetically connected to the Old Town (currently located on the outskirts) and stretches longitudinally throughout nearly the whole studied area. Its potential is especially high in the centre of the Historic Urban Core: several parallel street routes mark the central space of the city, visibly belt-shaped in nature. The area has its own specificity (vast quarters and post-industrial areas, among others), co-determining its current condition, yet it has configurational priority in fulfilling the central functions in this system.

The changes in the degree of the correlation between choice and integration values also indicate a direction of the evolution of the analysed layout (Table 2). 
Table 2. Pearson's coefficient of the correlation between choice and integration values calculated for natural streets in analysed plans

\begin{tabular}{|l|c|c|c|}
\hline \multicolumn{1}{|c|}{$\begin{array}{c}\text { Time period } \\
\text { (marks as in fig. 1) }\end{array}$} & R & $\mathbf{R}^{2}$ & P-value \\
\hline I (early 19th century) & 0.9498 & 0.9021 & 0.001 \\
\hline II (mid-19th century) & 0.7148 & 0.5110 & 0.001 \\
\hline III (the 1870s) & 0.7991 & 0.6386 & 0.001 \\
\hline IV (late 19th century) & 0.6017 & 0.3620 & 0.001 \\
\hline V (21st century) & 0.5634 & 0.3175 & 0.001 \\
\hline
\end{tabular}

Source: own work.

The value of the correlation index decreases with each analysed plan (with the exception of time period III - the first stage of filling the urban layout). It indicates that the complexity of a city plan increases with time. In pre-industrial Łódź, spaces with high integration values also had high choice values, while spaces with low integration values had low choice values. Therefore, from the topological perspective, both the topological centres and outskirts of Łódź of that time could be clearly identified in terms of both analysed features. The current values of these features are much more divergent. This divergence is not very strong (as shown in a generalised way in Figures 11 and 12), but confirms a larger diversification of the analysed area and, therefore, a lower predictability of the socio-economic processes occurring there. The spaces theoretically most often selected by pedestrians do not necessary have the highest integration values and vice versa: rarely selected routes can have the lowest integration values.

The outskirts of the studied territory visible on its geometrical edges should be assessed carefully, since the study was limited to the inner zone of the modern city. The information about the configurational peripheries 'rooted' in the Historic Urban Core, often in the direct neighbourhood or within the belt of the central zone, is much more valuable. These places are, similarly to the central zone, special in certain aspects. They are usually small, short spaces, located out of the way of the flows that occur within the city. Their air-tight nature provides certain 'locality in the centre', which may increase the attractiveness of these spaces (in terms of location) for some residents, facilitating the shaping of good neighbourhoods (as perceived by Jane Jacobs). However, for that same reason their isolation may result in the development and strengthening of negative social and economic phenomena.

The south-eastern part of the central Historic Urban Core is also peripheral in nature. Its internal integration is poor. This is caused by the presence of the railway line and station operating in this part of the city. The railway has been 
dividing the urban structures of the city for over 150 years, producing the effects in the configuration of its central part that are visible to this day. In the 2010s, the railway line and station were moved underground. This railway investment, one of the most modern and biggest ones in Europe, is part of the established New Centre of Łódź. However, in the context of the intended, central rank of the area, its position on the configurational map of the city centre, despite the restructuring of the street network, is still not optimal. There is a visible lack of an axis that would integrate the area both internally and with the central city zone.

Yet another interesting and crucial phenomenon is the problem of the progressing configurational marginalisation of the Old Town. The notion, however, is hard to assess due to the spatial nature of the analyses conducted.

The choice measure has identified those spaces in the layout that are the most attractive to travellers due to their topological properties (Fig. 12). Theoretically, they entail the important responsibility to ensure the efficient movement of travellers. At the same time, these can be spaces particularly at risk of being pressured by movement floods. The efficient functioning of whole central Łódź and, therefore, the whole city depends, to a major degree, on their 'friendliness' to the flows of people, that is the traffic capacity, and the clarity and quality of route surface. Streets with the lowest choice values may be less frequently chosen by travellers due to 'the nature of the layout'. Therefore, it can be assumed they are not as important for ensuring the efficient circulation of residents and users of the city.

The space of the Historic Urban Core of Łódź is diverse with regards to the integration level (Fig. 13). The most integrated part is made up of the orthogonal street layout, resembling an inverted letter L (or letter F). It can be assumed that the intensity of traffic resulting from a beneficial configurational location is relatively high there, thus facilitating social contact. The streets are attractive in terms of location for businesses that benefit from the presence of potential clients. Spaces with the lowest integration, which are theoretically less frequented (marked in grey), are at the other end of the scale.

\section{DISCUSSION AND CONCLUSION}

The specificity and the difference in the development of individual parts of the territory of a city is set on the relatively strong foundations created by its plan. In the long term, it may be of crucial significance to city functioning. The configuration of a city plan may slowly diversify social and economic processes occurring within the city. In this context, the actions whose functional program is in a spatial mismatch with the configurational determinants may end in failure revealed after a longer time. 
The configurational analysis has shown a contemporary, internal diversity of the Historic Urban Core. It is determined by a strong changeability of choice and integration values in the centre of the studied area. The close vicinity of areas that are central or marginal in terms of configuration is surprising in light of the orthogonal and relatively monotonous layout of the street network. The topological features of space in Łódź probably influence the currently noticeable diversity of economic processes in the Historic Urban Core. This conclusion requires a further, separate study (currently in preparation), yet a series of topologically peripheral streets in Łódź appears synonymous with areas of socio-economic collapse (partially under revitalisation).

The analyses facilitate the assessment of the stability/changeability of the Historic Urban Core plan only to some extent. Historically, the city centre was relatively young, shaped within the last 200 years. Its evolution up until now has mostly involved a territorial expansion and densification of the street network as well as a temporary (in light of the actions planned and conducted) 'freezing' of the plan in the 21 st century.

Undoubtedly, the most permanent and stable element of the plan of Łódź is the extended, axial (belt-shaped) centre. It is genetically anchored in the medieval urban layout and constitutes its contemporary, vast continuation. The marginal location of numerous streets of Łódź, similarly to the central location (in the topological sense) was imposed by the plan upon their creation. This was the case mostly with streets created in the late 19th century. To this day, they have remained in their rigid configurational framework, which may influence their developmental path.

The contemporary transformations to the Historic Urban Core of Łódź aim at improving the quality of life of its inhabitants. In this context, it is important to consider the predispositions of individual areas of the city, resulting from its plan arrangement. The knowledge of the hidden consequences of the city plan makes it possible to obviate the dangers it causes and, simultaneously, set the social and economic activity more aptly in space. The activity does not always involve a physical intervention in the urban tissue, which is usually hard to conduct. It may involve micro-scale, but also long-term programs aimed at maintaining the social and economic activities, creating a sense of community, and increasing the attractiveness of a place on both the physical and symbolic level (genius loci).

It would be advisable for Łódź to pay particular, long-term attention to the areas with low integration values identified in the city centre. Some of them are currently undergoing revitalisation involving, for instance, the transformation of streets into woonerfs. However, these actions without the improvement of the local typological features of the layout may, in some cases and in the long term, prove insufficient to really streamline their functioning. Movement conditions in spaces with the highest intensity of pedestrian traffic should also be improved. This may largely facilitate the implementation of the idea of new urbanism as well as the creation of liveable sustainable communities. 
The improvement in the integration of the New Centre of Łódź with its surroundings, and especially the axial core of the Historic Urban Core, would also be reasonable. The implementation of new, clear and pedestrian-friendly transport solutions between these two vital city areas should be considered. The merely mentioned peripheral location of the Old Town, which lost its city-wide, central functions during the time of territorial development, is also crucial and requires separate research.

By dint of the established theoretical foundations as well as specific research methods, space syntax makes it possible to analyse the contemporary and historical images of the city, as well as the process of its evolution. Space syntax supplements the traditional model representing urban space, based on geometrical relations, with an approach based on topological relations. Both models should be considered complementary images of the same reality. The model proposed by space syntax, due to the relatively short development period and potential that is still being discovered, appears more interesting from both theoretical and empirical perspectives.

Both the presented and quoted studies indicate that space syntax methods make it possible to obtain results that are spatially precise in context. Aside from the cognitive advantages, space syntax is also an advantageous practical tool. The only long-term goal of building or transforming urban structures is to obtain an environment in which the socio-economic processes will be successfully conducted. Space syntax can facilitate the fulfilment of such aims by limiting the situations where an investment implemented is shortly abandoned for other, more competitive places. Moreover, the continuous monitoring of configurational transformations can provide important data on the functioning of the whole urban organism.

\section{REFERENCES}

AHMED, B., HASAN, R. and MANIRUZZAMAN, K.M. (2014), 'Urban Morphological Change Analysis of Dhaka City, Bangladesh, Using Space Syntax', International Journal of Geo-Information, 3 (4), pp. 1412-1444. https://doi.org/10.3390/ijgi3041412

AL-SAYED, K., TURNER, A., HILLIER, B., IIDA, S. and PENN A. (2014), Space Syntax Methodology, University College of London, https://discovery.ucl.ac.uk/id/eprint/1415080/ [accessed on 09.01.2020].

AUTODESK Inc. (2020), AutoCAD Civil 3D. (Version 2020) [Computer software], Autodesk Inc., San Rafael CA.

AZIMZADEH, M. and BJUR, H. (2007), 'The urban palimpsest: the interplay between historical generated layers in the urban spatial system and urban life', [in:] KUBAT, A.S., ERTEKIN, O., GUNEY, Y.I. and EYUBOGLU, E. (eds.), Proceedings of the 6th International Space Syntax Symposium, 012.1-012.14, Istanbul Technical University, http://www.spacesyntaxistanbul.itu. edu.tr [accessed on: 09.01.2020]. 
BAFNA, S. (2003), 'Space syntax: A brief introduction to its logic and analytical techniques', Environment and behavior, 35 (1), pp. 17-29. https://doi.org/10.1177/0013916502238863

BARAN, P.K., RODRÍGUEZ, D.A. and KHATTAK, A.J. (2008), 'Space syntax and walking in a new urbanist and suburban neighbourhoods', Journal of Urban Design, 13 (1), pp. 5-28. https://doi.org/10.1080/13574800701803498

BATAGELJ, V. and MRVAR, A. (2019), Pajek - Program for Large Network Analysis (Version 5.08., 32 bit) [Computer software].

CHIARADIA, A., HILLIER, B., BARNES, Y. and SCHWANDER, C. (2009), 'Residential property value patterns in London', [in:] KOCH, D., MARCUS, L. and STEEN, J. (eds.), Proceedings of the 7th International Space Syntax Symposium, 15.1-15.12, Stockholm, http://www.sss7.org [accessed on: 09.01.2020].

DIAS, C.R. and de ARRUDA CAMPOS, M.B. (2015), 'Urban evolution of the Rio de Janeiro Port', [in:] KARIMI, K., VAUGHAN, L., SAILER, K., PALAIOLOGOU, G. and BOLTON, T. (eds.), Proceedings of the 10th International Space Syntax Symposium, 57.1-57.12, University College London, [accessed on: 09.01.2020] https://www.tib.eu/en/search/?tx_tibsearch_search\%5Bdocid\%5D=TIBKAT\%3A1008926116\&tx_tibsearch_search\%5Bcontroller\%5D=Download\&-

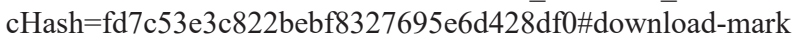

ENSTRÖM, R. and NETZELL, O. (2008), 'Can space syntax help us in understanding the intraurban office rent pattern? Accessibility and rents in downtown Stockholm', The Journal of Real Estate Finance and Economics, 36 (3), pp. 289-305.

Environmental Systems Research Institute, 2015, ArcGIS Desktop (Version 10.2) [Computer software].

FATHI, S., SAJADZADEH, H., MOHAMMADI SHESHKAL, F., ARAM, F., PINTER, G., FELDE, I. and MOSAVI, A. (2020), 'The role of urban morphology design on enhancing physical activity and public health', International journal of environmental research and public health, 17 (7), p. 2359. https://doi.org/10.3390/ijerph17072359

Geodesy Center in Lodz. (n.d.). InterSIT 2020. Lodz Internet Area Information System. https:// www.mapa.lodz.pl/

Georeference Database of Topographic Objects. Regional Surveying and Cartographic Documentation Centre in Łódź. [Unpublished data].

GRIFFITHS, S. (2012), 'The use of space syntax in historical research: current practice and future possibilities', [in:] GREENE, M., REYES, J. and CASTRO A. (eds.), Proceedings of the 8th International Space Syntax Symposium, 8193.1-8193.26, Pontificia Universidad Católica de Chile, $\mathrm{http}: / / \mathrm{sss} 8 . \mathrm{cl} /$ proceedings.html [accessed on: 09.01.2020].

HILLIER, B. (2007), Space is the Machine: A Configurational Theory of Architecture, London: Space Syntax.

HILLIER, B. and HANSON, J. (1984), The Social Logic of Space, Cambridge: Cambridge University Press.

HILLIER, B., LEAMAN, A., STANSALL, P. and BEDFORD, M. (1976), 'Space Syntax', Environment and Planning B: Planning and Design, 3 (2), pp. 147-185.

HILLIER, B., PENN, A., HANSON, J., GRAJEWSKI, T. and XU, J. (1993), 'Natural movement: or, configuration and attraction in urban pedestrian movement', Environment and Planning B: planning and design, 20 (1), pp. 29-66. https://doi.org/10.1068/b200029

JANIK, M., KUSIŃSKI, J., STĘPNIEWSKI, M. and SZAMBELAN, Z. (2012), Łódź na mapach: 1793-1939, Wydawnictwo Jacek Kusiński.

JIANG, B. (2009), 'Ranking spaces for predicting human movement in an urban environment', International Journal of Geographical Information Science, 23 (7), pp. 823-837. https://doi. org/10.1080/13658810802022822

JIANG, B. (2015), Axwoman. An ArcGIS extension for urban morphological analysis (Version 6.3) [Computer software], http://giscience.hig.se/binjiang/Axwoman/ [accessed on: 17.04.2019]. 
JIANG, B. and CLARAMUNT, Ch. (2002), 'Integration of space syntax into GIS: new perspectives for urban morphology', Transactions in GIS, 6 (3), pp. 295-309. https://doi.org/10.1111/14679671.00112

JIANG, B. and LIU, C. (2009), 'Street-based topological representations and analyses for predicting traffic flow in GIS', International Journal of Geographical Information Science, 23 (9), pp. 1119-1137. https://doi.org/10.1080/13658810701690448

JIANG, B., ZHAO, S. and YIN, J. (2008), 'Self-organized natural roads for predicting traffic flow: a sensitivity study', Journal of Statistical Mechanics: Theory and experiment, 7, pp. 1-27. https://doi.org/10.1088/1742-5468/2008/07/P07008

KARIMI, K., AMIR, A., SHAFIEI, K., RAFORD, N., ABDUL, E., ZHANG, J. and MAVRIDOU, M. (2007), 'Evidence-Based Spatial Intervention for Regeneration of Informal Settlement: the case of Jeddah central unplanned areas', [in:] KUBAT, A. S., ERTEKIN, Ö., GÜNEY, Y.I. and EYÜBOGLU E. (eds.), Proceedings of the 6th International Space Syntax Symposium, 034.01-034.14, Istanbul Technical University, http://www.spacesyntaxistanbul.itu.edu.tr [accessed on: 09.01.2020].

KIM, H.K. and SOHN, D.W. (2002), 'An analysis of the relationship between land use density of office buildings and urban street configuration: case studies of two areas in Seoul by space syntax analysis', Cities, 19 (6), pp. 409-418. https://doi.org/10.1016/S0264-2751(02)00071-9

KOSTAKOS, V. (2010), 'Space syntax and pervasive systems', [in:] JIANG, B. and YAO X. (eds.), Geospatial Analysis and Modelling of Urban Structure and Dynamics, pp. 31-52, Springer, https://link.springer.com/book/10.1007/978-90-481-8572-6 [accessed on: 05.01.2020]

KROPF, K. (1996), 'Urban tissue and the character of towns', Urban Design International, 1 (3), pp. 247-263. https://doi.org/10.1057/udi.1996.32

Łódź City Hall (2020), Łódź Rewitalizacja. Program Rewitalizacji Łodzi 2026+. https://rewitalizacja.uml.lodz.pl/rewitalizacja/co-to-jest-rewitalizacja/gminny-program-rewitalizacji-miasta-lodzi

MARSHALL, S. (2009), Cities, design and evolution, Abingdon, New York: Routledge.

MONTELLO, D.R. (2007), 'The contribution of space syntax to a comprehensive theory of environmental psychology', [in:] KUBAT, A.S., ERTEKIN, O., GUNEY, Y.I. and EYUBOGLU, E. (eds.), Proceedings of the 6th International Space Syntax Symposium, 012.1-012.14, Istanbul Technical University, http://www.spacesyntaxistanbul.itu.edu.tr [accessed on 08.09.2020].

NETTO, M.V. (2016), "«What is space syntax not?» Reflections on space syntax as sociospatial theory', Urban Design International, 21 (1), pp. 25-40. https://doi.org/10.1057/udi.2015.21

NILUFAR, F. (2010), 'Urban morphology of Dhaka city: Spatial dynamics of growing city and the urban core', [in:] Proceedings of International Seminar Proceedings on the Celebration of 400 Years of the Capital Dhaka, Asiatic Society, Dhaka, Bangladesh, https://www.academia. edu/245137/Urban_Morphology_of_Dhaka_City_Spatial_Dynamics_of_Growing_City_and_ the_Urban_Core [accessed on: 18.03.2020].

NUBANI, L. and WINEMAN, J. (2005), 'The role of space syntax in identifying the relationship between space and crime', [in:] VAN NES, A. (ed.), Proceedings of the 5th International Space Syntax Symposium, 1, pp. 413-422, Techne Press, http://spacesyntax.tudelft.nl, [accessed on: 18.08.2019].

ÖNDER, D.E. and GIGI, Y. (2010), 'Reading urban spaces by the space-syntax method: A proposal for the South Haliç Region', Cities, 27, pp. 260-271. https://doi.org/10.1016/j.cities.2009.12.006

PAFKA, E., DOVEY, K. and ASCHWANDEN, G. (2018), 'Limits of space syntax for urban design: Axiality, scale and sinuosity', Environment and Planning B: Urban Analytics and City Science, 47 (3), pp. 508-522. https://doi.org/10.1177/2399808318786512

PORTA, S., LATORA, V., WANG, F., RUEDA, S., STRANO, E., SCELLATO, S., CARDILLO, A., BELLI, E., CÀRDENAS, F., CORMENZANA, B. and LATORA, L. (2012), 'Street centrality and the location of economic activities in Barcelona', Urban Studies, 49 (7), pp. 1471-1488. https://doi.org/10.1177/0042098011422570 
RAFORD, N., CHIARADIA, A. and GIL, J. (2007), Space syntax: the role of urban form in cyclist route choice in central London, UC Berkeley Research Reports, University of California. UC Berkeley: Safe Transportation Research \& Education Center, https://safetrec.berkeley.edu [accessed on: 18.03.2020].

RATTI, C. (2004), 'Space syntax: Some inconsistencies', Environment and Planning B: Planning and Design, 31 (4), pp. 487-499.

SAEID, A.A.H. and MASZTALSKI, R. (2009), 'Spatial analysis of urban network of Wrocław', Europa XXI, 12, pp. 71-89, https://europa21.igipz.pan.pl/article/item/12193.html [accessed on: 21.01.2020].

SCELlATO, S., CARDILlO, A., LATORA, V. and PORTA, S. (2006), 'The backbone of a city', The European Physical Journal B-Condensed Matter and Complex Systems, 50 (1-2), pp. 221225. https://doi.org/10.1140/epjb/e2006-00066-4

SHARMIN, S. and KAMRUZZAMAN, M. (2018), 'Meta-analysis of the relationships between space syntax measures and pedestrian movement', Transport Reviews, 38 (4), pp. 524-550. https://doi.org/10.1080/01441647.2017.1365101

Statistical Office in Łódź. (2014) Łódź Population Projection 2015-2050, https://lodz.stat.gov.pl/ download/gfx/lodz/pl/defaultaktualnosci/752/4/11/1/201412_r_aneks_prognoza_ludnosci_statystyka_lodzi_2014.pdf [accessed on: 18.03.2020].

TEKLENBURG, J.A.F., TIMMERMANS, H.J.P. and VAN WAGENBERG, A.F. (1993), 'Space syntax: standardised integration measures and some simulations', Environment and Planning B: Planning and Design, 20 (3), pp. 347-357. https://doi.org/10.1068/b200347

TRIGUEIRO, E.B.F. and MEDEIROS, V. (2007), 'The bridge, the market, a centrality forever lost and some hope', [in:] KUBAT, A.S., ERTEKIN, Ö., GÜNEY, Y.I. and EYÜBOGLU E. (eds.), ,Proceedings of the 6th International Space Syntax Symposium, 036.01-036.12, Istanbul Technical University, http://www.spacesyntaxistanbul.itu.edu.tr [accessed on: 20.03.2020].

UCL Space syntax, (n.d.), UCL Space syntax: Online Training Platform. https://otp.spacesyntax.net.

VAN NES, A. and LÓPEZ, M. (2010), 'Macro and micro scale spatial variables and the distribution of residential burglaries and theft from cars: an investigation of space and crime in the Dutch cities of Alkmaar and Gouda', The Journal of Space Syntax, 1 (2), pp. 296-314, http://128.40.150.106/joss/index.php/joss/article/view/296/pdf_25 [accessed on: 20.03.2020].

VAUGHAN, L. and PENN, A. (2006), 'Jewish immigrant settlement patterns in Manchester and Leeds 1881’, Urban Studies, 43 (3), pp. 653-671. https://doi.org/10.1080/00420980500535146

WANG, F., JIANG, C., LI, W., LI, J. and ZHU, X. (2018), 'What changes? What remains? The evolution of the street networks in old Beijing city over one century', Journal of Spatial Science, 63 (2), pp. 203-223. https://doi.org/10.1080/14498596.2018.1479985 